\title{
Conditionals in Moroccan Arabic
}

\author{
Abdelhakim Boubekri \\ Mohamed V University, Morocco
}

\begin{abstract}
This study describes conditional constructions in Moroccan Arabic (henceforth MA) using a cognitive approach. Adopting the tripartite classification of conditionals namely factual, hypothetical, and counterfactual by Comrie (1986), this study examines conditional constructions that are introduced by the particles ila (إl) and kun (كون). The analysis shows that there are two basic types of conditional constructions in MA depending on whether the 'if-clause' represents a possible condition (real conditional) as in: ila ilacbu mazyan, irabhu 'If they play well, they will win'; or a contrary-tofact/impossible condition (unreal conditional) as in kun ğa, nəmšiw kamlin 'If he came, we would go'. In real conditional constructions,
\end{abstract}

\footnotetext{
Abdelhakim Boubekri

$\mathrm{Ph} . D$. candidate in Second Language Acquisition Studies, Department of English, Faculty of Education Sciences, Mohamed V University-Rabat, Morocco

Email: boubekri755@gmail.com
}

Received 28 June, 2018; Revised 2 Septmber, 2018; Accepted 1 October, 2018

Copyright @ 2019 Language Research Institute, Sejong University Journal of Universal Language is an Open Access Journal. All articles are distributed online under the terms of the Creative Commons Attribution Non-Commercial License (http://creativecommons.org/licenses/by-nc/3.0) which permits unrestricted non-commercial use, distribution, and reproduction in any medium, provided the original work is properly cited. 
the particle ila is used in conditional constructions to signal the condition and the future. Ila allows two verb forms in both the protasis and the apodosis, namely, the perfective as in ila git, rani git 'If you came, I came', and the imperfective form as in ila kan haddam, nhalsu 'If he is working, I will pay him'. However, each form is used in a special and different way.

In unreal conditionals, the various particles are used to signal solely the condition. There are three types of unreal conditionals. The first one refers to the present, the second refers to the future, and the third refers to the past. Concerning verb forms, there are three possible patterns. The first one is that the verb in both the protasis and the apodosis is in the perfective form as in kun $\breve{g} a$, kun $l c z b$ 'If he had come, he would have played'. The second one is that the verb in both the protasis and the apodosis is in the imperfective form as in kun iği, ilçb 'If he comes, he will play'. The third one is that the verb in the protasis is in the perfective form, while the verb in the apodosis is in the imperfective form as in $k$ un $\breve{g} a$, ilc $ə b$ 'If he came/had come, he would play/would have played'. The meanings of the verb form whether it is in the perfective or the imperfective, depend on their use in the protasis and the apodosis.

Keywords: imperfective, perfective, real/unreal conditional

\section{Introduction}

Conditional constructions manifest the cognitive power of humans to examine miscellaneous situations and to infer consequences on the basis of known or hypothetical conditions. It has been assumed that almost all languages have a way to form conditional sentences; therefore conditionals do exist in natural languages of the world if not all. Classical Greek, German, Standard Arabic, Latin, Chinese, Japanese are examples of natural languages in which conditional constructions do exist (Traugott 1986). This study describes conditional 
constructions in MA adopting the tripartite classification of conditionals namely factual, hypothetical, and counterfactual by Comrie (1986). It examines conditional constructions that are introduced by the particles ila (إلا) and kun (كون).

\section{Theoretical Background}

\subsection{Conditionals}

Conditional constructions are marked by their multi-faceted nature which makes it quite difficult to provide a definition that can hold for the full range of conditional usages. Accordingly, Declerck \& Reed (2001: 8) state that "the number of criteria that can be used to categorize conditionals and the number of ensuing types and subtypes is so large that we have found it impossible to identify a genuine common denominator". Likewise, Wierzbicka (1997: 54) claims that "the meaning of the English word condition is semantically more complex than that of [the lexical primitive] IF". Even more, as indicated by Declerck \& Reed (2001: 8), the view that a conditional clause is a subordinate clause, and thus syntactically and semantically dependent on a 'main clause', is not very practical. For one reason, there are paratactic conditionals like Do it and/or I'll beat you. For another, the sort of semantic dependency of an if-clause on its main clause may vary considerably.

The only form that gains a clear agreement among researchers to represent conditionals is the one referred to as If $p$, (then) $q$ (Comrie 1986, Evans \& Over 2004). Dancygier (1999: 1), following traditional grammarians, defines "conditionals" as "the sentences so labelled by grammarians (rather than logicians): complex sentences; composed of 
the main clause (sometimes also called q, or the apodosis) and a subordinate clause ( $\mathrm{p}$, or the protasis). The subordinate clause is introduced by a conjunction, the least marked of English conditional conjunction being if'. Likewise, Bennett (2003) describes a conditional sentence as a sentence that embraces two clauses: the main clause and the subordinate clause. The latter is introduced by a conditional conjunction. In English, conditional constructions are introduced by if, unless and a few other conjunctions. From the above definitions, we can say that a conditional sentence is characterized by the unassertiveness of its propositions, contains two clauses: a main clause and a subordinate clause, the subordinate clause is introduced by a conjunction such as if and unless in English, Pin 'if' (noncounterfactual) and law 'if' (counterfactual) in Standard Arabic, and jodi 'if' and with a conditional, non-finite verb form -le in Bengali.

\subsection{Aspect in Moroccan Arabic}

Aspect is a defining feature of many grammatical structures such as conditionals in Moroccan Arabic. It plays a major role in defining the different categories of conditionals. Comrie (1976: 3) defines aspects as the "different ways of viewing the internal temporal constituency of a situation". He indicates that there are two types of aspect perfective and imperfective:

the perfective looks at the situation from outside, without necessarily distinguishing any of the internal structure of the situation, whereas the imperfective looks at the situation from inside, and as such is crucially concerned with the internal structure of the situation, since it can both look backwards towards the start of the situation, and look forwards to the end of the situation, and indeed is equally appropriate if the 
situation is one that lasts through all time, without any beginning and without any end."

(ibid: 4)

He contrasts it with tense which is defined as "the grammaticalization of location in time" (Comrie 1985: 1). That is to say "It locates situations in time, usually with reference to the present moment, though also with reference to other situations" (ibid: 5). Since MA is a dialect that has its roots in Modern Arabic, I will adopt Comrie's (1976) account to Modern Arabic in respect with aspect to indicate MA as an aspectual dialect. He indicates that verbs in Modern Arabic are either perfectives or imperfectives. The Perfectives indicate relative past time, while the Imperfectives indicate relative non-past (present or future) time (ibid: 80). Verbs in MA behave in the same way. Consider the following examples:

a. ddrari

ləcbu

lbarəh

DEF-boy-PL ${ }^{1}$ play-PFV-3PP yesterday

'The boys played yesterday'

b. *ddrari

iləcbu

lbarəh

DEF-boy-PL play-IPFV-3PP yesterday

'The boys played yesterday'

(2)
a. ddrari
ka-ilə⿳亠口冋u
daba
DEF-boy-PL
dur-play-3PP
now
'The boys are playing now'

\footnotetext{
1 Here is a list of abbreviations used in this article: DEF=Definite article; $\mathrm{PFV}=$ Perfective aspect; IPFV=Imperfective aspect; $1 \mathrm{SP}=$ First singular person; $2 \mathrm{SP}=$ Second singular person; $3 \mathrm{SP}=$ Third singular person; $1 \mathrm{PP}=$ First plural person; $2 \mathrm{PP}=$ Second plural person; $3 \mathrm{PP}=$ Third plural person; $\mathrm{PL}=\mathrm{Plural} ; \mathrm{ADV}=$ Adverb; $\mathrm{ADJ}=$ Adjective; NOM=Noun; DUR=Durative; IMP=Imperative; NEG=Negation; $\mathrm{Q}=\mathrm{Quantifier}$, ESL=English as a Second Language; EFL=English as a Foreign Language.
} 

b. *ddrari loc bu daba DEF-boy-PL play-PFV-3PP now 'The boys played now'
(3) a. ddrari gadi iləcbu ġdda DEF-boy-PL will play-IPFV-3PP tomorrow 'The boys will play tomorrow'
b. *ddrari gadi $1 \partial^{c} \mathrm{bu}$ gədda DEF-boy-PL will play-PFV-3PP tomorrow 'The boys will played tomorrow'

From these examples, it is clear that perfectives refer to the past. This is supported by the use of the perfective verb lacbu 'play' with the adverb lbarzh 'yesterday' in example (1a). However, the use of the imperfective verb ilac $b u$ 'play' with the adverb lbarzh 'yesterday' results in ungrammatical sentence in example (1b). The imperfective indicates non-past. This is supported by the use of the imperfective verb ilac $b u$ 'play' with the adverbs daba 'now' and gadda 'tomorrow' in examples (2a) and (3a) respectively. However, the use of the perfective verb $l a^{c} b u$ 'play' with the adverbs $d a b a$ 'now' and gadda 'tomorrow' in examples (2b) and (3b) respectively results in ungrammatical sentences.

The use of the perfective is possible only in the future in MA. It can be used with time reference to indicate perfective meaning in the future. This is done by combining the imperfective of the verb kan 'to be' (here functioning as an auxiliary) and the perfective of the main verb. To illustrate, consider the following examples:

$$
\text { a. ddrari gadi ikunu la fodak lwəqt }
$$
DEF-boy-PL will be-IPFV-3PP play-PFV-3PP at that time 'The boys will have played at that time' 
b. *ddrari ikunu lacbu daba DEF-boy-PL be-IPFV-3PP play-PFV-3PP now 'The boys are playing now'
c. *ddrar
ləcbu
kull nhar fhad lwoqt
DEF-boy-PL play-PFV-3PP every day at this time 'The boys play every day at this time'

Example (4a) shows that the perfective form of the verb is possible in the future in MA. This is only possible when it is combined with the auxiliary ikun 'be' in the imperfective form in the precedent position. In this case, it indicates the perfect meaning of the verb in the future time. However, the use of the perfective form of the verb in the present with the auxiliary verb or without results in ungrammatical sentences as in (4b) and (4c). It is impossible in both the continuous present as in sentence (4b), and the habitual present as in sentence (4c).

The imperfective form is possible in the past. It can be used with time reference to indicate imperfective meaning in the past, as in Classical Arabic (ibid: 80). To indicate the imperfective past, the perfective form of the verb kan 'to be' (here functioning as an auxiliary) is combined with the imperfective form of the main verb. To illustrate, consider the following example:
a. ddrari
kanu
ilacbu
DEF-boy-PL be-PFV-3PP play-IPFV-3PP
molli ttasəlti
lbarəh
when call-PFV-2SP yesterday
'The boys were playing when you called yesterday' 
b. *ddrari iləcbu molli ttasəlti lbarəh DEF-boy-PL play-IPFV-3PP when call-PFV-2PS yesterday 'The boys were playing when you called yesterday'

Example (5a) shows that the imperfective form is possible in the past. However, it cannot be used independently. It requires an auxiliary verb, in this case kan 'to be' to indicate the imperfective meaning in the past. This justifies the ungrammaticality of sentence (5b).

To summarize, we may say that in MA, the perfective indicates both perfective meaning and relative past time reference, while the imperfective indicates everything else (i.e., either imperfective meaning or relative non-past tense). The Arabic opposition Imperfective/ Perfective incorporates both aspect and (relative) tense. In the following section, I will consider Comrie's (1986) classification of conditionals to try a classification to MA conditionals.

\section{Moroccan Arabic Conditionals in Light of Comrie's (1986) Classification}

\subsection{Introduction}

Several parameters are suggested by Comrie (1986) to describe conditional constructions in human languages, including clause order, marking of conditionality, degrees of hypotheticality and time reference. The most important factors are the last two: hypotheticality and time reference. Hypotheticality is defined by Comrie (1986: 88) as "the degree of probability of realization of the situations referred to in the conditional and more especially in the protasis." Languages show different degrees of hypotheticality along a continuum with no 
clear divisions (ibid.). The speaker evaluates the degree of hypotheticality of the proposition, and then he chooses the conditional type accordingly (ibid.). In English conditionals, degrees of hypotheticality are expressed using different tenses (past, present and future) and modals (would or any other modal) (Chou 2000). The three-way distinction (past/present/future) is maintained in conditionals with low hypotheticality. The present/future distinction is neutralized in the protasis, while it is retained in the apodosis. In conditionals with greater hypotheticality, however, the present/future distinction is neutralized in both the protasis and apodosis.

The well-known typology of conditional constructions is the tripartite system based on the degree of factuality of the events encoded in each of the two clauses (Comrie 1986, Johnson-Laird 1986, Jacobsen 2012). The tripartite system includes three key terms as Taylor (1997: 301-302) listed. (i) Factual conditionals, also called 'real' or 'realis' (Dancygier \& Sweetser 2005): the content of the if-clause is presumed to be the case. (ii) Hypothetical conditionals, also called 'irrealis' (ibid.): the content of the if-clause is entertained as a possibility, neither in accordance with reality, nor necessarily inconsistent with it. (iii) Counterfactual conditionals, also referred to as 'unreal' (ibid.): the content of the if-clause is taken to be contrary to fact. This system is the most adopted by most ESL/EFL course books of English, including the Moroccan ones.

In light of this classification, this study deals with conditional constructions in MA. It examines conditionals that are introduced by the conjunctions ila (إلان), lukan (كوكان), kun kan (وكان), kun (كون), kun kan (كون كان), ukan (وكان) (Caubet 2005). Most of linguists (Ennaji et al. 2004, Caubet 2005) agree that there are two basic types of conditional sentences in MA depending on whether the "if-clause" represents a possible condition or a contrary-to-fact/impossible condition. The first type is introduced by the conjunction ila (إl) 
which is equivalent to "if" in English, while the second type is introduced by the other conjunctions lukan (لوكان), uka kan (وكان), (وكان), kun (كون), kun kan (كون كان), ukan (وكان). All of these conjunctions are equivalent to "if" and play the same role "if" does in English. The choice of which conjunction to use depends on which part in Morocco the speaker belongs to. For instance, Fasi people use $u k a$ kan (وككان), while Casawi people use kun (كون) and lukan (لوكان). Therefore, I will limit myself to the use of kun (كون) since it is the most used one all over Morocco. Accordingly, there are two parts in this study. The first one is devoted to conditional constructions that are introduced by the conjunction ila (l). These constructions represent a possible condition. This part is divided to three sections: the protasis is discussed in the first one, the apodosis is discussed in the second one, and verb forms are discussed in the third one. The second part is devoted to the conditional constructions that are introduced by the conjunction kun (كون). This section is divided into the same sections, which are the protasis, the apodosis and verb forms.

\subsection{Real Conditionals: The Conditional Construction with ila (إلإ)}

Conditional constructions that are used to represent real conditionals are introduced by the conjunction ila (l). In the protasis, the time reference introduced by ila is the future. In the apodosis, the time reference is also the future if there is a causal or sequential relation between the two clauses. Thus, ila is used in the conditional construction to signal the condition and the future. What are the possible types of the main clause/ the protasis?

${ }^{2}$ Fasi peopel are the people who live in Fez (Fez is a city in the middle of Morocco). Casawi people are the people who live in Casablanca (Casablanca is a city in the north-west of Morocco). 


\subsubsection{The Protasis in Real Conditionals}

In this section, I aim to present the possible types of sentences that are used in the protasis with the conjunction ila. All of the sentences that I came across in the books that analyze MA conditionals, I did not find a sentence without a verb (Ennaji et al. 2004, Caubet 2005). Therefore, I dare to claim that there is always a verb in the protasis with the conjunction ila otherwise it is ungrammatical. Like the conditionals in Standard Arabic (Alotaibi 2014), the sentence in the protasis in MA must be a declarative sentence. The role of declarative sentence is to make statements. Thus, Paul has come is a declarative sentence (Matthews 2007). That is, it cannot be interrogative. The role of interrogative sentence is to ask questions. It is opposite to the declarative sentence. Thus, Has Paul come? is an interrogative sentence (ibid.). It cannot be imperative. The role of imperative sentence is to give orders. Thus, go home is an imperative sentence (ibid.). It cannot also be exclamative. It is opposite to questions, statements, requests, etc. It is a sentence like How wonderful that would be! (ibid.). In such sentences, the verb is either in the perfective or imperfective form, but it does not refer to the past or to the present as in regular sentences. In such conditional constructions, the protasis can contain kan in both the perfective and imperfective forms. To illustrate the perfective and imperfective forms of the verb in the protasis, the following are best examples:
a. ila iləcbu
məzyan irəbḥu
If play-IPFV-3PP well-ADV win-IPFV-3PP
'If they play well, they will win'
b. ila $1 \partial^{\mathrm{c} b u}$
məzyan irəbhu
If play-PFV-3PP well-ADV win-IPFV-3PP
'If they play well, they will win' 
In MA, like the use of kana in the perfective form and ikun in the imperfective form in Standard Arabic, kan is used in the perfective and ikun is used in the imperfective form in the protasis. Like the perfective kana and the imperfective yakunu in Standard Arabic, the perfective kan and the imperfective ikun do not have unreal interpretation and they indicate the same tense and mood as lexical verbs.
a. ila kan
Anas
hədam,
if be-PFV-3SP Anas-NOM work-IPFV-3SP-DUR
ka-ihdəm Kamal
work-3SP Kamal
'If Anas is working, Kamal will work'
b. ila ikun has hədam, hətta
if be-IPFV-3SP Anas-NOM work-too-IPFV-3SP
Kamal ihdəm
Kamal work-IPFV-3SP
'If Anas is working, Kamal will work, too'

The use of the perfective kan in sentence (7b) does not mean to refer to the past, it denotes tense in the hypothetical situation which means 'suppose it is the case'. This can be said also for the imperfective ikun. Both kan and ikun denote tense as lexical verbs do. The only difference between them and lexical verbs is that the latters denote both tense and event, while the formers denote just tense (Alotaibi 2014: 114). The perfective kan and the imperfective ikun can be auxiliary verbs referring the time reference. They always precede the verb. Consider the following examples: 
(8)

a. ila kan ihdəm, nhəlsu if be-PFV-3P work-IPFV-3SP pay-IPFV-1SP

'If he is going to work, I will pay him'

b. ila ikun ihdəm, nhəlsu

if be-IPFV-3SP work-IPFV-3SP pay-IPFV-1SP

'If he is working, I will pay him'

Example (8a) exemplifies the use of the future progressive and the habitual future while example ( $8 b$ ) exemplifies the use of present progressive.

Kan can also be used to indicate existence and it is used with a subject only, as in the following example:

$\begin{array}{llll}\text { (9) ila kan } & \text { rqiq, } & \text { idhəl } \\ \text { if } & \text { be-PFV-3SP } & \text { skinny-ADJ } & \text { get in-IPFV-3SP }\end{array}$ 'If he's skinny, he will get in'

Another expression plays the same role of kan is rah. The difference between the two lies in the fact that rah cannot be used to refer to the future as in sentence (10c), and it cannot be used with a subject only as in sentence (10d). It can be used to refer to past, as in sentence (5a), and to present progressive only, as in sentence (10b).
a. ila rah
həddam,
həllih
if be-PFV-3SP work-IPFV-3SP let-IMP-3SGM

'If he is working, let him'

b. ila rah

ğay,

həllih

if be-PFV-3SP come-IPFV-3SP let-IMP-3SP

'If he is coming, let him' 


$$
\begin{aligned}
& \text { c. *ila rah iği, } \\
& \text { if be-PFV-3Sp come-IPFV-3P } \\
& \text { 'If he will come, let him' } \\
& \begin{array}{l}
\text { d. *ila rah } \\
\text { if rqiq, }
\end{array} \\
& \text { 'If he's skinny, he will get in' }
\end{aligned}
$$

\subsubsection{The Apodosis in Real Conditionals}

Many types of sentences can be found in the apodosis due to the limited syntactic constraints it has. In this section, I will present these types specifically the sentences introduced by gadi 'will', hotta 'too', $k a$ 'durative', rani 'then', and the bare apodosis.

$\dot{G} a d i$ in MA is used to convey various meanings which are 'a sequential meaning', 'and then', as in sentence (11a), a resultative meaning 'and so' as in sentence (11b), a causal relationship as in sentence (11c):

(11) a. ila tləbtu

monha, gadi təctih liya if request-IPFV-1SP from her will give-IPFV-3SP to me 'If I request it from her, she will give it to me'

b. ila qra, ġadi inğəh if study-PFV-3SP will succeed-IPFV-3SP

'If he studies, (then) he will succeed'

c. ila taḥt

šta, gadi inbət $Z r^{\mathrm{c}}$ if fall-PFV-3SP rain-NOM will grow-IPFV-3SP grain-NOM 'If it rains, the grain grows' 


$$
\begin{aligned}
& \text { d. *ila qra, } \quad \text { gadi } \quad \text { nağəh } \\
& \text { if study-PFV-3SP will succeed-PFV-3SP } \\
& \text { 'If he studies, (then) he will succeed' }
\end{aligned}
$$

$\dot{G} a d i$ cannot be used with verbs in the perfective form, hence the ungrammaticality of sentence $(6 \mathrm{~d})$.

Hotta 'too' can be used with both the verbs in the perfective form as in sentence (12b), and the verbs in imperfective form as in sentence (12a). When it is used with verbs in the perfective form, as in sentence (12a), or with the verbs in the imperfective form, it indicates a sequential meaning as in sentence (12b):
a. ila qra,
ḩətta Pana nəqra
If study-PFV-3SP too me study-IPFV-1SP
'If he studies, so I will study, too'
b. ila qra, ḥətta Pana qrit
if study-PFV-3SP too me study-PFV-1SP
'If he studies, so I will study, too'

$\mathrm{Ka}$ 'durative' is used to indicate a sequential meaning as well. It indicates also a causal relationship, as in (13c). There is a constraint on the use of $k a$ 'durative'. The verb in the protasis cannot be used in the imperfective form. Consider the following examples:
a. ila qrit, ka-iqra
if read-PFV-1SP
DUR-read-IPFV-3SP
'If I read, he reads'
b. *ila kanəqra, ka-iqra if read-IPFV-1SP DUR-read-IPFV-3SP
'If I am reading, he will read'




\section{c. ila taḩət šta, \\ if fall-PFV-3SP rain-NOM \\ ka-inbət $\quad$ zər $^{c}$ \\ DUR-grow-IPFV-3SP grain-NOM \\ 'If it rains, the grain grows'.}

Rani 'then' is used with both verbs, the ones that are in the perfective form as in sentence (14a), and the ones that are in the imperfective form as in sentence (14b). It indicates a sequential meaning. Interestingly, there is conformity between the verbs used with rani. Therefore, if the first is in the past, the second is in the past as well. This is true only for the cases in which the apodosis is clearly a result of the protasis as in sentences (14a), (14b), and (14c). However, when the protasis does not identify the circumstances in which the proposition of the apodosis is true, there is no conformity between the verb form of the protasis and that of the apodosis, as in sentence (14d). In other words, I am sleeping whether the protasis is fulfilled or not (i.e., whether or not he comes). In this case, the apodosis is clearly not the result of the protasis. In fact, the apodosis in example (14d) seems to have been fulfilled before the speaker has uttered the sentence whereas the protasis has not been fulfilled yet. Sentence (9d) can be paraphrased as if he comes, then it is relevant for him to know that I am sleeping. This kind of conditional sentences is called relevance conditional (Alotaibi 2014: 117).
a. ila
ğit,
rani
$\breve{g i t}$
if come-PFV-3SP then
come-PFV-1SP

'If you came, I came' 
b. ila ğay, rani ğay if come-IPFV-3SP then come-IPFV-1SP 'If you are coming, then I'm coming'

c. ila tği, rani nği if come-IPFV-3SP then come-IPFV-1SP 'If you will come, then I will come'

d. ila ğa, $\quad$ rani $\quad$ nacəs if come-PFV-3SP then sleep-IPFV-1SP 'If he comes, I am sleeping'.

The last type of apodoses that belongs to the constructions introduced by ila is the bare apodosis. The bare apodosis can exist in almost all conditional types that introduced by ila in the protasis. This includes indicative, exclamative, and interrogative forms. It can also be used to express all types of meanings. There is no exception to this generalization. The bare apodosis cannot be used to express a past relationship between the protasis and the apodosis, hence the ungrammaticality of the following example:

$\begin{array}{lll}* \text { ila } & \text { ga }, & \text { ncəst } \\ \text { if } & \text { come-PFV-3SP } & \text { sleep-PFV-1SP } \\ \text { 'If he came, I slept' } & \end{array}$

Negation is expressed using the 'ma...s'. 'Ma...š' is used to negate a state of affairs in the present as in sentence (16a), and is used with gadi in the future as in sentence (16b). However, it needs kun to negate a state of affairs in the past as in sentence (16c). 
(16)
a. ila ğa,
ma-tği-šs
if come-PFV-3SP NEG-come-IPFV-2SP
'If he comes, don't come'
b. ila ğa, ma-ġadi-š nği if come-PFV-3SP NEG-will come-IPFV-2SP 'If he comes, I won't come'

c. ila ğa, nkun ma-ğit-š if come-PFV-3S be-IPFV-1SP NEG-come-IPFV-2SP 'If he came, I wouldn't have come'

Sentence (16c) is different from all the examples mentioned above since it belongs to the unreal conditional type. Therefore, this is a case where an ila conditional construction can be used to express unreal conditionals in MA.

To sum up, different types of apodoses are used in the conditional constructions introduced by ila. The use of particles depends on the time reference expressed in the conditional construction. For instance, rani cannot be used with a verb in the past in the apodosis.

\subsubsection{Verb Forms in Real Conditionals}

A conditional sentence in MA with the conjunction ila allows two verb forms in both the protasis and the apodosis, namely, the perfective and the imperfective form. However, each form is used in a special and different way in conditional sentences. For example, the verb in the perfective form (which has the past interpretation in declarative sentences) is used with the future interpretation of the verb in the protasis that is introduced by ila and in the apodosis if the relation between the two clauses is a causal relation. In addition, the verb in 
the imperfective form (which usually has the present interpretation) is also used with the future interpretation in the protasis and in the apodosis if the relation is causal.

The whole conditional construction introduced by ila has the future as its time reference when this construction has a causal relationship. That is to say, the fulfillment of the protasis allows for the fulfillment of the apodosis.

As 'if' in English, ila in MA marks the non-assertiveness of the conditional construction. It is a conjunction that connects between the protasis and the apodosis.

In MA, the form of the two verbs in the protasis and apodosis can be both in the perfective form. If the protasis is in the perfective form, the apodosis can be in the perfective form. That argues for the grammaticality of sentence (15) above. Both verbs can be also in the perfective form when they are used with two particles namely hatta and $r a h$, as in the following example:

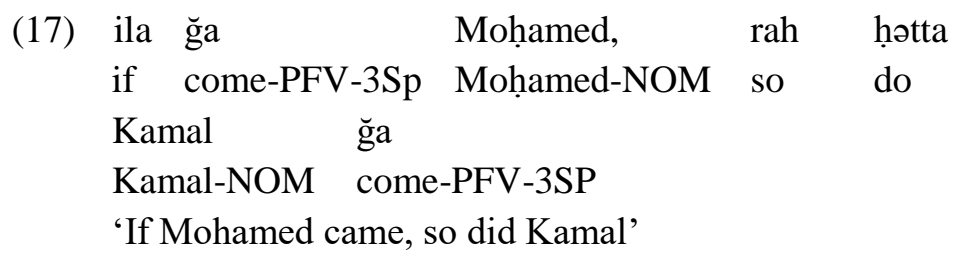

In sentence (17), the relation between the protasis and the apodosis is not causal, since the fulfillment of the apodosis does not follow from the fulfillment of the protasis.

Unlike Standard Arabic (Alotaibi 2014: 133), when an adverb referring to the past, such as lbarzh 'yesterday', or the present such as daba 'now', is used in the protasis where the verb is in the perfective form, the sentence will be grammatical as in ila $\breve{g} a$ Mohamed lbarzh/daba. The use of the adverb daba 'now' with a 
sentence like (17) will result in an ungrammatical sentence. However, the use of the adverb lbarzh 'yesterday' will result in a grammatical sentence.

The two verbs in the apodosis and protasis can be both in the imperfective form as in (14b) and (14c). The time reference in these cases is the future. Contrary to sentence (17), the adverb daba 'now' can be used with (14b) and (14c), however lbarah 'yesterday' cannot.

In a nutshell, when the relationship is causal between the protasis and the apodosis, the time reference of the verbs, either perfective or imperfective, is the future. In this case, the time reference of the protasis precedes the time reference of the apodosis. Unlike English, but like Standard Arabic, MA verb forms do not determine the type of the conditional with the conjunction ila. What is the relationship between the verb form in the protasis and the verb form in the apodosis?

Like Standard Arabic (ibid: 135), there are differences between the two verb forms in the meaning. These differences depend on the belief of the speaker towards the fulfillment of the protasis or the apodosis. When the speaker uses a verb in the perfective form in the clause, he suggests that the clause will be fulfilled. On the other hand, when the speaker uses a verb in the imperfective form, he aims to show that the fulfillment of the clause is uncertain but it is possible.

Sentences (13a) and (13b) and many previous examples mentioned above, suggest that the verb forms in the protasis and apodosis can be different. Therefore, it is possible to find the perfective form in the protasis and the imperfective form in the apodosis such as in (13a). It is also possible to find the imperfective form in the protasis and the perfective form in the apodosis as in ila ğay, Pana rani ğit 'if you are coming, I have come already'. In this case, the addition of rani is obligatory. The relationship between the protasis and the apodosis is causal in (13a), therefore the verb form in the protasis is 
perfective, while the verb form in the apodosis is imperfective. However, when the verb form in the protasis is imperfective, while the verb form in the apodosis is perfective, the relation between the two is not causal. In the example ila ğay, Pana rani ğit 'if you are coming, I have come already', the relationship is not causal. It is a speech act whereby the speaker informs the hearer that he has come if he is coming. In this case the time reference of the protasis is the future, while the time reference of the apodosis is the past. The time reference in sentence (13a) (ila qrit, ka-iqra 'If I read, he reads'), is the future in both the protasis and the apodosis. This does not apply that the time reference is always the future when the verb form is in the perfective form in the protasis, and in the imperfective form in the apodosis. This suggests that it is the case when the relationship is causal, while it is not when the relation is not causal as in ila ğit, rani gay 'if you have come, I am coming'. The sentence in this case belongs to the speech act conditional since the sentence means 'if you are already there wait for me. I'm coming'.

Some conclusion can be drawn from the previous discussion:

i. Unlike Standard Arabic (Alotaibi 2014), not all the constructions of conditionals with the conjunction ila are real conditionals. In some cases, the speaker has negative belief towards the fulfillment of the conditional with this conjunction as in (16c).

ii. The use of a verb in the perfective or imperfective form in the protasis expresses the speaker's attitude towards the fulfillment of the clause. Therefore, if he uses the perfective form in the protasis, it means that he has a positive attitude towards the fulfillment of the conditional in the clause. However, the use of the imperfective form in the protasis, it means that he has a negative attitude towards the fulfillment of the conditional in the clause. 
iii. The use of the perfective or imperfective forms in the apodosis, in addition to some expressions, expresses the strength or weakness of the relationship between the fulfillment of the protasis and the apodosis. For instance, ila git, rani ğay 'if you have come, I am coming', the word rani plus the use of the imperfective form make the fulfillment of the condition strong in this clause.

\subsection{Unreal Conditionals: The Conditional Constructions with kun (كون)}

There are two types of conditionals: real conditionals which are introduced by ila conjunction, and unreal conditionals. There are many conjunctions that are used to introduce unreal conditionals namely lukan (لوكان), ukakan (وكان), kun (كون), kun kan (كون (كان), and ukan (وكان). All of these conjunctions are equivalent to 'if' and play the same role 'if' does in English. As has been mentioned above (cf. 1.3.1), the choice of which conjunction to use depends on which part in Morocco the speaker belongs to. Therefore, I will limit myself to the use of kun (كون) since it is the most used one all over Morocco. There are three types of unreal conditionals. The difference between them depends on the time reference they refer to. Before we indulge in the presentation of the difference types of unreal conditionals, the following are examples to argue for the fact that the different conjunctions used to introduce unreal conditionals play the same role:

$$
\begin{aligned}
& \text { a. kun/lukan/ukakan/kun kan/ukan tği, } \\
& \text { if } \\
& \text { come-IPFV-2SP } \\
& \text { nəmšiw kamlin } \\
& \text { go-IPFV-1PP all-Q } \\
& \text { 'If you just come, we will all go' }
\end{aligned}
$$


b. kun/lukan/ukakan/kun kan/ukan ğiti, if come-PFV-2SP

$\begin{array}{ll}\text { nəmšiw } & \text { kamlin } \\ \text { go-IPFV-1PP } & \text { all-Q }\end{array}$

'If you came, we would all go'

c. kun/lukan/ukakan/kun kan/ukan

ğiti, if come-PFV-2SP

kun mšina

be go-PFV-1PP

'If you had come, we would have gone'

d. kun/lukan/ukakan/kun kan/ukan

ma-ğiti-š, if NEG-come-PFV-2SP

ma-nəmšiw-š

NEG-go-IPFV-1PP

'If you hadn't come, we wouldn't have gone'

These examples clearly show that the different conjunctions used to introduce unreal conditionals are used in constructions which refer to different time reference. Therefore, they play the same role. Thus, I will limit myself to the use of kun.

The difference between the three unreal conditional types is in time reference. Accordingly, the first type is used to refer to the future as in sentence (18a). In this sentence, the speaker expects that the addressee will not come. Therefore, the fulfillment of the condition is contrary to expectation. The second type is used to refer to the present as in sentence (18b). In this sentence, the speaker assumes that the addressee did not come. Therefore, the fulfillment of the condition is contrary to the assumption. The third type is used to refer to the past as in sentence (18c). In this sentence, the speaker 
assumes that the addressee had not come. Therefore, the fulfillment of the condition is contrary to the assumption.

The meanings of unreal conditionals are sometimes ambiguous if they are treated out of context. Consider the following example:

$\begin{array}{lll}\text { kun } & \text { ləcbu, } & \text { irəbhu } \\ \text { if } & \text { play-PFV-3PP } & \text { win-IPFV-3PP }\end{array}$

'If they played/had played, they would/could win/would/ could have won'

There are three possible readings for this sentence: (i) if they played, they would win in the future, (ii) if they played, they could win now, (iii) if they had played, they would have won in the past. We can test our claim using adverbs like, gadda 'tomorrow', daba 'now', and lbarzh 'yesterday'. Let's test sentence (19) using the three adverbs. kun lacbu gadda, irabhu 'If they played tomorrow, they would win', in this sentence, the speaker expects that the players will not play tomorrow; therefore, they will not win. kun lacbu daba, irabhu 'If they played now, they could win', in this sentence, the speaker assumes that the players do not play now; therefore, they could not win. kun lacbu lbarzh, irabhu 'If they had played yesterday, they would have won', in this sentence, the speaker states that the players did not play yesterday; therefore, they did not win.

The next section is divided into three sections, namely the protasis, the apodosis and verb forms. As have been noted before, I will introduce just the unreal conditionals introduced by the conjunction kun.

\subsubsection{The Protasis in Unreal Conditionals}

Kun, like many other conjunctions, introduces unreal conditionals 
in MA. Its role is to mark the conditional construction as counterfactual. There are two types of protases in the unreal conditionals namely protases with lexical verbs, and protases with kan plus the lexical verb. Unlike Standard Arabic (Alotaibi 2014: 140), the protasis in MA unreal conditionals cannot have a sentence without a verb. There is a common point between the protases introduced by ila and the protases introduced by kun, specifically, the fact that both of them must be a declarative sentence. Therefore, they cannot be interrogative, imperative, or exclamative.

Like the protasis of conditional constructions introduced by ila, the protasis of conditional constructions introduced by kun can contain a verb in the perfective and imperfective form as illustrated below:

$\begin{array}{clll}\text { a. kun } & \text { ləcbu, } & \text { kun } & \text { rəbḥu } \\ \text { if } & \text { play-PFV-3PP } & \text { be } & \text { win-PFV-3PP }\end{array}$

'If they had played, they could have won'

$\begin{array}{lll}\text { b. kun iləcbu, } & \text { kun } & \text { irəbhu } \\ \text { if } \quad \text { play-IPFV-3PP } & \text { be } & \text { win-IPFV-3PP } \\ \text { 'If they played, they could win' } & \end{array}$

Like sentence (19), sentence (20a) has three possible readings out of context. Consequently, the time reference can be the future, the present, or the past as has argued above. However, since the conditional sentence (20b) has the imperfective form in the protasis, this makes it unable to refer to the past. It can just refer to the present and the future.

Unlike Standard Arabic, as has mentioned above, the sentence in the protasis cannot be a sentence without a verb bearing in mind that kan is considered a verb as illustrated below: 
(21)
kun kan
kbir,
kun dditu
mªya
if be-PFV-3SPmature-ADJ be-PFV take-PFV-3SP with me 'If he was/had been mature, I would take/have taken him with me'

The verb kan here plays two roles: (i) the role that a lexical verb plays in ordinary sentences, and (ii) to mark a strong relation between the protasis and the apodosis. This idea is credited to Cantarino (1974: 322) who states that 'since law cannot be followed by a noun, when it introduces a nominal or an inverted verbal sentence, ?anna is used after the conditional particle'. In this statement Cantarino does not treat kan, but he treats the particle Panna in Standard Arabic. By a close scrutiny to a sentence in MA that contains the verb kan and a sentence in Standard Arabic contains the particle Panna, it becomes clear that they play the same role which is to emphasize a strong relation between the protasis and the apodosis in unreal conditionals. Consider the following example:

$\begin{array}{llll}\text { law } & \text { Pannahū kabīr, } & \text { la dahaba } & \text { maci } \\ \text { if be that } & \text { mature-ADJ } & \text { go-PFV-3SP } & \text { with me }\end{array}$

It is clear that kan in sentence (21) and Panna in sentence (22) play the same role. They maintain the idea that if the protasis was fulfilled, the apodosis would be definitely fulfilled.

Both the perfective and the imperfective forms of kan can be used in the protasis. Consider the following examples:
a. kun kan
fərḥan,
kun tləa $\vartheta^{c} \quad$ lgəlsa if be-PFV-3SP happy-ADJ be great sit-NOM 'If he had been happy, we would have had fun' 


\section{b. kun ikun fərhan, kun tləa lgəlsa if be-IPFV-3SP happy-ADJ be great Sit-NOM 'If he was happy, we would have fun'}

The interpretation of sentence (23a) is that it can have three readings, as sentences (19) and (20a) mentioned above. And this can be proved using the test of the adverbs gadda 'tomorrow', daba 'now', and lbarah 'yesterday'. However, sentence (23b) can have two interpretations, the first one refers to the present time reference, and the second refers to the future time reference. The first interpretation is that the speaker does not expect the fulfillment of the protasis in the future which means that he expects that the addressee will not be happy in the future. The second interpretation is that the speaker does not assume the fulfillment of the protasis in the present which means that the addressee is not happy when the speaker utters the sentence. This sentence cannot be used to refer to the past since when it is used with the adverb lbarzh 'yesterday', it becomes ungrammatical (*kun ikun farhan lbarəh, kun tlac lgalsa).

In a nutshell, the perfective form of the verbs in the protasis of unreal conditionals introduced by kun can refer to the future, the present, or the past. However, the imperfective form can only refer to the future or the present.

\subsubsection{The Apodosis in Unreal Conditionals}

The apodosis in the conditional construction introduced by kun can be in a declarative, exclamative, or interrogative sentence. It cannot be in an imperative sentence. Consider the following examples:
a. kun
lcəb,
irbəh
if
study-PFV-3SP
succeed-IPFV-3SP 
'If he plays/played/had played, he will win, would/could win, would/could have won'

b. kun $1^{c} ə b$, muhạalš irbəh if study-PFV-3SP impossible-ADJ succeed-IPFV-3SP 'If he plays/played/had played, he may not win, might not win, might have not won'

c. kun lcəb, waš irbəh? if study-PFV-3SP will win-IPFV-3SP

'If he studied, will/would he win?'

$$
\begin{array}{cll}
\text { d. *kun lcobti, } & \text { rbəh } \\
\text { if } & \text { play-PFV-2SP } & \text { win-IMP-2SP } \\
\text { 'If you played, win!' } &
\end{array}
$$

The declarative sentence in the apodosis can be introduced by kun, as in sentence (25), or can be a bare apodosis, as in sentence (24a).

$\begin{array}{llll}\text { kun lo } ə \text { b, } & \text { kun } & \text { rbəh } \\ \text { if } & \text { play-PFV-3SP } & \text { be } & \text { win-PFV-3SP }\end{array}$

'If he played/had played, he would/could win, would/could have won'

Kun can be used with both verb forms perfective and imperfective. For instance, in example (25), the verb either used in the perfective or the imperfective form will result in a grammatical sentence. Therefore, we can say both kun rbəh or kun irbəh. Kun plays two roles in the apodosis. The first role is that it allows the use of the perfective form of the verb in the apodosis. The second one is that it signals the strong relationship between the fulfillment of the protasis 
and the apodosis. However, in the bare apodosis, the verb form can be just in the imperfective. This argues for the ungrammaticality of sentence (24d). It is important to note that the apodosis cannot exist without a verb.

The exclamative sentence in the apodosis allows the use of some adjectives, in addition to the stress used on certain syllables to signal the surprise the speaker has concerning the positive or the negative fulfillment of the apodosis. For instance, the use of the adjective muhalš 'impossible' signals the negative fulfillment of the apodosis.

The interrogative sentence in the apododsis can be marked by the use of waš 'will'. The speaker asks whether the apodosis will be fulfilled or not. He does not have any attitude toward the fulfillment of the apodosis either positive or negative.

\subsubsection{Verb Forms in Real Conditional}

Verb forms in unreal conditionals can have either the same verb form in the protasis and the apodosis, or the verb form in the protasis is different from the one in the apodosis. This section will discuss the sentences with the same verb forms in the protasis and the apodosis, and the sentences with different verb forms in the protasis and the apodosis.

Verbs can be in the imperfective form in the protasis and the apodosis. In this case, the interpretation of the conditional construction will be ambiguous. This is because it can receive two interpretations: the first one is that the sentence refers to the present, and the second is that it refers to the future. To illustrate, consider the following example:
(26) kun iği,
ilcob
if come-IPFV-3SP
play-IPFV-3SP
'If he comes, he will play' 
This sentence belongs to unreal conditional sentences. It receives two interpretations: in the first one the time reference is the present. That is to say, the speaker assumes that the person referred to in the sentence does not come in the present; therefore, he does not play. To argue for the validity of our interpretation, we check whether the protasis would be grammatical if we use the adverb daba 'now'. In MA, it is grammatical to say kun iği daba, ilc $ə b$ 'if he comes now, he will play'. Therefore, our argument is valid.

The second interpretation is that sentence (26) refers to the future. That is to say, the speaker assumes that the person referred to in the sentence will not come in the future; therefore, he will not play. To argue for the validity of our interpretation, we check whether the protasis would be grammatical if we use the adverb gadda 'tomorrow'. In MA, it is grammatical to say kun iği ġdda, ilc $ə b$ 'if he comes tomorrow, he will play'. Therefore, our argument is valid.

If the adverb lbarzh 'yesterday' is used in the protasis in sentence (26), it will result in an ungrammatical sentence. Hence, in MA, it is not grammatical to say kun iği lbarzh, ilcəb 'if he came yesterday, he would play'.

Concerning, the perfective form, a sentence which has a verb in the perfective form in the protasis and a verb in the same form in the apodosis, receives three interpretations. The context is the only decisive criterion concerning which interpretation is correct. To illustrate, consider the following example:

$\begin{array}{llll}\text { kun } & \text { lcəb, } & \text { kun } & \text { rbəh } \\ \text { if } & \text { play-PFV-3SP } & \text { be } & \text { win-PFV-3SP }\end{array}$

'If he plays/played/had played, he will/would/could/would /could have won'

There are three possible readings for this sentence: (i) if he played, 
he would win in the future, (ii) if he played, he could win now, (iii) if he had played, he would have won in the past. We can test our claim using adverbs like, gadda 'tomorrow', daba 'now', and lbarzh 'yesterday'. Let's test sentence (25) using the three adverbs. kun lcab gadda, kun rbah 'If he played tomorrow, he would win', in this sentence, the speaker expects that the player will not play tomorrow; therefore, he will not win. kun lc $ə b$ daba, kun rbəh 'If he played now, he could win', in this sentence, the speaker assumes that the player does not play now; therefore, he could not win. kun løb lbarah, kun rboh 'If he had played yesterday, he would have won', in this sentence, the speaker states that the player did not play yesterday; therefore, he did not win. It is important to indicate that the verb in the perfective form in the apodosis cannot stand alone. Therefore, the following sentence is ungrammatical:

$$
\begin{aligned}
& \text { *kun lcəb, rbəh } \\
& \text { if play-PFV-3SP win-PFV-3SP } \\
& \text { 'If he plays/played/had played, he will/would/could/would } \\
& \text { /could have won' }
\end{aligned}
$$

Unreal conditionals do not always have the same verb form in the protasis and apodosis. There is a third possibility which is that the protasis has the perfective form and the apodosis has the imperfective form. To illustrate, consider the following example:

$$
\begin{aligned}
& \text { kun lcəb, irbəh } \\
& \text { if play-PFV-3SP win-IPFV-3SP } \\
& \text { 'If he plays/played/had played, he will/would/could/would } \\
& \text { /could have won' }
\end{aligned}
$$

Sentence (29) receives the same interpretations as sentence (27). 
The only difference between the two is the use of kun in the apodosis of sentence (27). As has mentioned before, kun in sentence (27) plays tow roles. The first role is that it allows the existence of the perfective form of the verb in the apodosis. The second role is that it marks the fulfillment relationship between the protasis and the apodosis as strong. Concerning the possibility of having the imperfective form in the protasis and the perfective form in the apodosis, it results in an ungrammatical sentence. Consider the following example:

$\begin{array}{lll}\text { *kun } & \text { ilcəb, } & \text { rbəh } \\ \text { if } & \text { play-IPFV-3SP } & \text { win-PFV-3SP }\end{array}$

'If he plays/played/had played, he will/would/could/would /could have won'

If we use kun with the verb in the perfective form in the apodosis, it will lead to an ungrammatical sentence, as well. Consider the following example:

*kun ilcəb, kun rbəh
if play-IPFV-3SP be win-PFV-3SP
'If he plays/played/had played, he will/would/could/would
/could have won'

To conclude, there are three possible patterns of verb forms in unreal conditionals. The first pattern is that the verb in both the protasis and the apodosis is in the perfective form. This pattern necessitates the existence of the particle kun before the verb in the apodosis. The second pattern is that the verb in both the protasis and the apodosis is in the imperfective form. The third pattern is that the verb in the protasis is in the perfective form, while the verb in the 
apodosis is in the imperfective form. I have also mentioned that it is not possible to have a pattern in which the verb in the protasis is in the imperfective form, while the verb in the apodosis is in the perfective form. Concerning the meanings of the verb forms whether it is in the perfective or the imperfective, depend on their uses in the protasis and the apodosis. We argue that when the perfective form of the verb is used in the protasis, it results in three possible interpretations. These interpretations are related to the time reference of the conditional sentence. Accordingly, the conditional sentence refers to the past, the present, or the future. The context in which the conditional sentence is used is the only decisive criterion concerning which interpretation is correct. When a verb in the protasis is used in the imperfective form, this makes the sentence subject to two interpretations in the present or the future. Furthermore, when kun is used with a verb in the apodosis, it makes the fulfillment of the protasis more likely to happen. When the perfective form of the verb is used in the protasis, it makes the fulfillment of the protasis less likely to happen. However, when using a verb in the imperfective form in the protasis, it makes the fulfillment of the protasis more likely to happen.

The meanings of the verb forms in the apodosis depend on whether the verb is in the perfective or the imperfective. When it is in the perfective form it marks a strong relationship between the two clauses of the conditional sentence. However, when it is used in the imperfective form, it marks a weak relationship between the two clauses of the conditional sentence. That is to say, when the speaker uses the perfective form of the verb, he is more confident about the fulfillment of the apodosis. However, when he uses the imperfective form of the verb, he is less confident about the fulfillment of the apodosis. 


\section{Moroccan Arabic Conditionals and the Universality of Languages}

From the foregoing, it is clear that MA conditionals are characterized by some universal properties of natural languages. First, the most well-known universal about conditionals is Greenberg Universal of Word Order14: "In conditional statements, the conditional clause precedes the conclusion as the normal order in all languages" (Greenberg 1963: 66). This universal property is proved to be valid in MA sentences order. All the examples presented in the above sections argue for this fact. I do not claim that this is the only sentence order in MA. There are sentences in which the main clause precedes the conditional clause. This type of sentences is not frequent in MA, though. Second, Athanasiadou \& Dirven (1997: 62) state that: "the common factor of all conditionals - and consequently also the main feature of conditionality - is the mutual dependency between the two propositions in the sub-clause and in the main clause of conditional sentences." Likewise, there is a mutual dependency of the two propositions in the sub-clause and in the main clause in MA. Therefore, it is impossible to express conditionality without having the two clauses in MA. Third, in MA as in many other natural languages such as English, a prototypical conditional construction is If $p$, (then) $q$ as claimed by Dancygier \& Sweetser (2005). All the above examples have the form of the above prototypical construction. That is to say, the if-clause being the antecedent and the main-clause as the consequent of the conditions stated in the ifclause. Fourth, in almost all languages, there is a way of marking conditionality. In many natural languages, the subordinate clause is introduced by a conjunction such as if and unless in English (if marks 
most conditional sentences), Pin 'if' (noncounterfactual) and law 'if' (counterfactual) in Standard Arabic, and jodi 'if' and with a conditional, non-finite verb form -le in Bengali. In MA, many conjunctions introduce conditional sentences, namely ila (إلان), lukan (لوكان), uka kan (ككان), kun (كون), kun kan (كون كان), ukan (وكان) (Caubet 2007). Ila and kun are the most frequent ones. Ila introduces real conditionals and the other conjunctions introduce unreal conditionals. In general, conditionals in MA are characterized by conditional properties of most natural languages.

\section{Conclusion}

In this study, I describe conditional constructions in MA adopting the tripartite classification of conditionals suggested by Comrie (1986). The analysis shows that there are two basic types of conditional constructions in Moroccan Arabic depending on whether the 'ifclause' represents a possible condition (real conditional) or a contraryto-fact/impossible condition (unreal conditional). Real (factual and hypothetical) conditional constructions are introduced by the particle ila. Unreal (counterfactual) conditional constructions are introduced by various particles namely lukan (لوكان), ukakan (وكان), (وكان), kun kan (كان كون), and ukan (وكان). I limit myself to the use of kun (كون) since it is the most used one all over Morocco. In real conditional constructions, the particle ila is used in conditional constructions to signal the condition and the future. In addition, many particles are used to introduce the different sentences in the apodosis namely gadi 'will', hatta 'so', $k a$ 'durative', rani 'then', and the bare apodosis. Finally, conditional constructions in MA with the conjunction ila allows two verb forms in both the protasis and the apodosis, namely, 
the perfective and the imperfective form. However, each form is used in a special and different way.

In unreal conditionals, the various particles are used to signal solely the condition. There are three types of unreal conditional constructions. The difference between them depends on the time reference they refer to. There are two types of protases in the unreal conditional constructions namely protases with lexical verbs, and protases with kan plus the lexical verb. In the apodosis, there are two types of sentences, a sentence introduced by the particle kun and a bare apodosis. Concerning verb forms, there are three possible patterns of verb forms in unreal conditional constructions. The first pattern is that the verb in both the protasis and the apodosis is in the perfective form. The second pattern is that the verb in both the protasis and the apodosis is in the imperfective form. The third pattern is that the verb in the protasis is in the perfective form, while the verb in the apodosis is in the imperfective form. The meanings of the verb form whether it is in the perfective or the imperfective, depend on their use in the protasis and the apodosis.

\section{References}

Alotaibi, Y. 2014. Conditional Sentences in Modern Standard Arabic and the Taif Dialect. Ph.D. Dissertation, University of Essex.

Athanasiadou, A. \& R. Dirven. 1997. Conditionality, Hypotheticality, Counterfactuality. In A. Athanasiadou \& R. Dirven (eds.), On Conditionals Again 61-96. Amsterdam: John Benjamins Press.

Bennett, J. 2003. A Philosophical Guide to Conditionals. Oxford: Clarendon Press.

Cantarino, V. 1974. Syntax of Modern Arabic Prose: The Expanded 
Sentence II. Bloomington, IL \& London: Indiana University Press for the International Aairs Center.

Caubet, D. 2005. Generation darija! EDNA 9, 233-243.

Chou, C-L. 2000. Chinese Speakers' Acquisition of English Conditionals: Acquisition Order and L1 Transfer Effects. Second Language Studies Paper 19.1, 57-98.

Comrie, B. 1976. Aspect: An Introduction to the Study of Verbal Aspect and Related Problems. Cambridge: CUP.

Comrie, B. 1985. Tense. Cambridge: CUP.

Comrie, B. 1986. Conditionals: A Typology. In E. Traugott et al. (eds.), On Conditionals 77-99. Cambridge: CUP.

Dancygier, B. 1999. Conditionals and Prediction: Time, Knowledge, and Causation in Conditional Constructions. Cambridge: CUP.

Dancygier, B. \& E. Sweetser. 2005. Mental Spaces in Grammar: Conditional Constructions. Cambridge: CUP.

Declerck, R. \& S. Reed. 2001. Conditionals: A Comprehensive Empirical Analysis. Berlin: Mouton de Gruyter.

Ennaji, M. et al. 2004. A Grammar of Moroccan Arabic. Fès: University of Fès Publications.

Evans, J. \& D. Over. 2004. If. Oxford: OUP.

Greenberg, J. 1963. Some Universals of Grammar with Particular Reference to the Order of Meaningful Elements. In J. Greenberg (ed.), Universals of Language. Cambridge, MA: MIT Press.

Jacobsen, N. 2012. Applying Cognitive Linguistic and Task-Supported Language Teaching to Instruction of English Conditional Phrases. Unpublished Ph.D. Dissertation, Georgetown University.

Johnson-Laird, P. 1986. Conditionals and Mental Models. In E. Traugott et al. (eds.), On Conditionals 55-76. Cambridge: CUP. Matthews, P. 2007. The Concise Oxford Dictionary of Linguistics. Oxford: OUP. 
Taylor, J. 1997. Conditionals and Polarity. In A. Athanasiadou \& R.

Dirven (eds.), On Conditionals Again 289-306. Amsterdam: John Benjamins.

Traugott, E. et al. 1986. On Conditionals. Cambridge: CUP.

Wierzbicka, A. 1997. Conditionals and Counterfactuals: Conceptual Primitives and Linguistic Universals. In A. Athanasiadou, \& R. Dirven (eds.), On Conditionals Again 15-62. Amsterdam: John Benjamins Press. 